AWEJ for Translation \& Literary Studies Volume, 1 Number 3, August 2017

Pp.106-120

DOI: http://dx.doi.org/10.24093/awejtls/vol1no3.8

\title{
An Attempt at Applying Vladimir Propp's Morphology of the Folktale on Charles Dickens's Great Expectations
}

\author{
Khalid LAHLOU \\ Department of English, Faculty of Letters and Human Sciences \\ Hassan II University, Ben M'Sik, Casablanca, Morocco
}

\begin{abstract}
The present paper is an attempt at approaching Charles Dickens' Great Expectations from a morphological perspective based upon Vladimir Propp's Morphology of the Folktale. The paper is divided into two parts. The first part is concerned with a brief view of the nature of formalism: its background and its process of analysis. The second part is devoted to putting into practice what has been dealt with in the first part. It will be mostly concerned with the question as to whether all the functions of dramatis personae as stated by Propp figure in the object of analysis, Great Expectations. Finally, the paper will draw the conclusion as to whether the aforementioned elements constitute an organic unity.

Keywords: dramatis personae, folktale, formalistic reading, morphological substructure

Cite as: LAHLOU, K. (2017). An Attempt at Applying Vladimir Propp's Morphology of the Folktale on Charles Dickens's Great Expectations. Arab World English Journal for Translation \& Literary Studies, 1(3).

DOI: http://dx.doi.org/10.24093/awejtls/vol1no3.8
\end{abstract}

